\title{
Life Cycle Assessment of the Closed-Loop Recycling of Used Disposable Diapers
}

\author{
Norihiro Itsubo ${ }^{1}$, Mitsuhiro Wada ${ }^{2}$, Shigeo Imai ${ }^{2}$, Akira Myoga ${ }^{2}$, Naoki Makino ${ }^{3, *}$ and \\ Koichi Shobatake ${ }^{3}$ \\ 1 Faculty of Environmental Studies, Tokyo City University, 3-3-1 Ushikubo-nishi, Tsuzuki-ku, \\ Yokohama 224-8551, Japan; itsubo-n@tcu.ac.jp \\ 2 ESG division, Unicharm Corporation, 1531-7 Wadahama, Toyohama-cho, Kanonji, Kagawa 769-1602, Japan; \\ mitsuhiro-wada@unicharm.com (M.W.); shigeo-imai@unicharm.com (S.I.); \\ akira-myoga@unicharm.com (A.M.) \\ 3 TCO2 Co., Ltd., 23-2 Bancho, Chiyoda-ku, Tokyo 102-0082, Japan; shobatake@tco2.com \\ * Correspondence: makino@tco2.com; Tel.: +81-3-6272-6814
}

Received: 31 January 2020; Accepted: 12 March 2020; Published: 17 March 2020

\begin{abstract}
In Japan, approximately 23.5 billion paper diapers are produced annually (total of diapers for infants and adults produced in 2018). The majority of used paper diapers are disposed of through incineration; in certain regions, some paper diapers are recycled, mostly by open-loop recycling or thermal recycling. To date, several methods of recycling used paper diapers have been proposed and developed, but these methods are considered to have different types and amounts of recycled materials and different environmental performances. In this study, a new technology was developed for the closed-loop recycling of used paper diapers, and the use of the recycled pulp and superabsorbent polymer (SAP) as materials for paper diapers was evaluated via the environmental impact using the life cycle assessment (LCA) method, using data obtained from experimental facilities for recycling. The results between the comparison of the new method with the landfill and incineration processes demonstrate a greenhouse gas reduction of $47 \%$ and $39 \%$, respectively. The results also show that such recycling is expected to reduce land-use occupation and water consumption, closely related to the pulp, main raw material of paper diapers.
\end{abstract}

Keywords: disposable paper diaper; material recycling; closed-loop recycling; life cycle assessment (LCA)

\section{Introduction}

Paper diapers are roughly divided into two types: those for infants and those for adults. Paper diapers for infants, which are highly convenient as they do not require laundering like cloth diapers, are essential for daily life in Japan. Paper diapers for adults have also become indispensable, given the increasing number of persons requiring nursing care and the shortage of caregivers, in line with the progressive aging of society. In 2018, in Japan, the annual production of paper diapers for infants was approximately 15.1 billion, equal to 480,000 tonnes, while that of diapers for adults mainly used in nursing care facilities and medical institutions stood at about 8.4 billion, equal to about 390,000 tonnes [1]. The production volume has been increasing for 10 years, since 2010: 1.7 times for diapers for adults and 1.9 times for those for infants. Paper diapers for adults, in particular, are expected to further increase in the future, due to the rise in the elderly population [2].

Paper diapers consist of pulp or superabsorbent polymer (SAP) used as a moisture absorber, exterior materials, waterproof materials, and plastic materials such as polyethylene or polypropylene used in internal nonwoven fabric material. Pulp, which accounts for the majority of the materials, 
is made of virgin materials for needle bleached kraft pulp (NBKP, or nadelholz bleached kraft pulp in German). The annual consumption of materials for NBKP, SAP, and plastics is estimated at approximately $330,000,230,000$, and 250,000 tonnes, respectively, based on the annual production [1] and the material composition of paper diapers (study by Unicharm Corp.).

The majority of used paper diapers from general households are collected and incinerated by local governments as combustible waste in the category of domestic general waste [3]. Paper diapers are considered to cover $6 \%-7 \%$ of the total volume of household combustible waste, and the high moisture content due to excreta included in used paper diapers leads to a low calorific value, inhibiting heat recovery efficiency during combustion [4]. Used paper diapers from business operators such as nursing care facilities and hospitals are not collected by local governments in principle but instead are entrusted to special disposal companies who collect and incinerate them as general waste from business activities or specially controlled waste [5].

As such, used paper diapers are mostly incinerated in Japan, but there are also some efforts and study cases on the recycling of paper diapers. Fujiyama et al. [6] conducted an analysis and a comparison with incineration processing of the material recycling of recovered recycled pulp to be used for fireproof plates, in addition to the manufacture of refuse paper and plastic fuel (RPF) from the thermal recycling of used paper diapers. They reported that greenhouse gas (GHG) emissions from recycling can be reduced by about $37 \%$ compared with incineration. A study related to the recycling of water absorptive sanitary products $[7,8]$ also discussed thermal recycling treatment systems for processing used paper diapers recovered as they are, without separating or cleaning them, for conversion into solid fuel. Quantification of environmental loads adopting the life cycle assessment (LCA) is not confirmed, but reference was made to the possibility of reducing $\mathrm{CO}_{2}$ emissions by using them as boiler fuel instead of fossil fuel. In the recycling of used paper diapers targeted for studies reported by Itsubo et al. [9], the preceding report of this paper revealed that recycled pulp has the same quality as NBKP, the virgin material that is the main component of paper diapers, which shows that pulp can be closed-loop recycled. It is also indicated that GHG emissions can be reduced by about $26 \%$ compared with incineration, as well as significant reductions in water consumption and land use occupation, areas where the pulp is considered to have high potential effects.

The present study introduces a new recycling technology that achieves the closed-loop recycling of SAP. This new recycling technology adopts a new crushing/cleaning/separating technology and improves the recycling rate for pulp, etc., and recycles SAP to the same quality as virgin materials, where SAP was thermally recycled with the preceding recycling technology. The environmental load over the entire life cycle of paper diapers from the acquisition of raw materials to the disposal/recycling phases is quantified.

There have been several reports on the recycling of used disposable diapers overseas [7,10-13]. An LCA report [12], which collected data from an experimental-scale recycling plant, stated that plastics could be recycled and pulp containing SAP could be used to generate the steam needed for the sterilization process, which indicates that the environmental impact is reduced compared to landfill disposal.

Many previous studies have focused on climate change. Disposable diapers use paper as the main material, and the supply of chips, the main raw material for paper, requires a lot of land use and water consumption. Recycling of disposable diapers is expected to contribute to reducing the burden on water consumption and land use but has not been evaluated in previous studies. In this study, in addition to climate change, water consumption and land use are evaluated.

\section{Materials and Methods}

\subsection{Objective}

This study assesses the life cycle of paper diapers, including the closed-loop recycling that recycles pulp and SAP from used paper diapers into a quality product to be used as the raw material for paper 
diapers. The quantified environmental impacts are discussed and compared with those for incineration and landfill. In performing the LCA, an inventory analysis and impact assessment were conducted for the production, transportation, recovery, recycling, and disposal of disposable diapers in accordance with the international standard for ISO 14040 [14].

\subsection{Scope of This Study}

\subsubsection{Overview of Key New Technologies for Closed-Loop Recycling}

1. Crushing, Washing, and Separation Technologies

Used paper diapers are required to be degraded into composition materials such as pulp, SAP, and plastics for recycling. The crushing process is characterized by dissolving the diapers in an organic acid solution of $\mathrm{pH} 2.5$ or less, which prevents a reduction in treatment efficiency as there is no loss of liquidity in the treatment tank caused by the swollen highly water absorptive polymer [15]. It also has the effect of continuously securing hygiene in the facility, using a safe organic acid to enable safe treatment and to prevent odor and contamination. In conventional techniques using a water solution for the basic cleaning/separating process [9], SAP absorbs a large amount of moisture to become gel-like, losing its liquidity. This, in turn, greatly reduces the performance of the treatment equipment, making it necessary to use a large amount of lime to inactivate the SAP. Moreover, the use of hypochlorite as a disinfectant generates a highly alkaline environment in the treatment tank, which degrades the pulp fibers and lowers the pulp recovery rate and quality. Conventional techniques also require lengthy agitation and heating for separation, making it difficult to improve treatment efficiency. The process in this study, that is, applying the new technology, improved the recycling rate of SAP to about $80 \%$ and that of pulp also to about $80 \%$ compared to around $40 \%$ with conventional techniques [9].

\section{Ozone Treatment Technology}

Reusing the pulp recovered from the crushing/cleaning/separating process as raw materials for paper diapers requires that the pulp be recycled to a sufficient quality usable for sanitary materials. Ozone treatment uses ozone water to dissolve and solubilize SAP contained in the recovered pulp as residue, then discharges the ozone water to remove the SAP from the pulp, thereby extracting pulp ingredients only [16]. Ozone treatment also thoroughly sterilizes the pulp, eliminating the need for disinfectant. Moreover, ozone is returned to oxygen after use, without generating resistant bacteria, which improves the safety of recycled pulp.

\section{SAP Reactivation Technology}

As the SAP recovered from the crushing/cleaning/separating process is inactivated, it is necessary to recover the water absorption performance so that it can be used instead of virgin SAP [17]. Conventional techniques [9] use acid or alkaline treatment, which leaves the possibility of acid or alkaline residue in recycled SAP if not completely neutralized. Using such recycled SAP as raw materials for paper diapers may cause skin irritation, making it difficult to reuse as sanitary materials. However, the process targeted in this study makes it possible to recover the water absorption performance of SAP by neutralizing the SAP that has been inactivated by the organic acid solution.

4. Verification of the Quality and Safety of Recycled Products

The present study targeted closed-loop recycling, where pulp and SAP are recycled to a quality equal to that of virgin materials, and thus are usable as raw materials for paper diapers. The quality of the pulp was confirmed by consigning inspections about the standards stipulated by the Ministry of Health, Labour, and Welfare (MHLW) [18] to a third-party inspection organization. Inspection items and results are summarized in Table 1 . The recycled SAP was also confirmed to have a water 
absorption performance equal to that of SAP in virgin materials, and thus can be used as raw materials for paper diapers.

Table 1. Quality inspection results of recycled pulp.

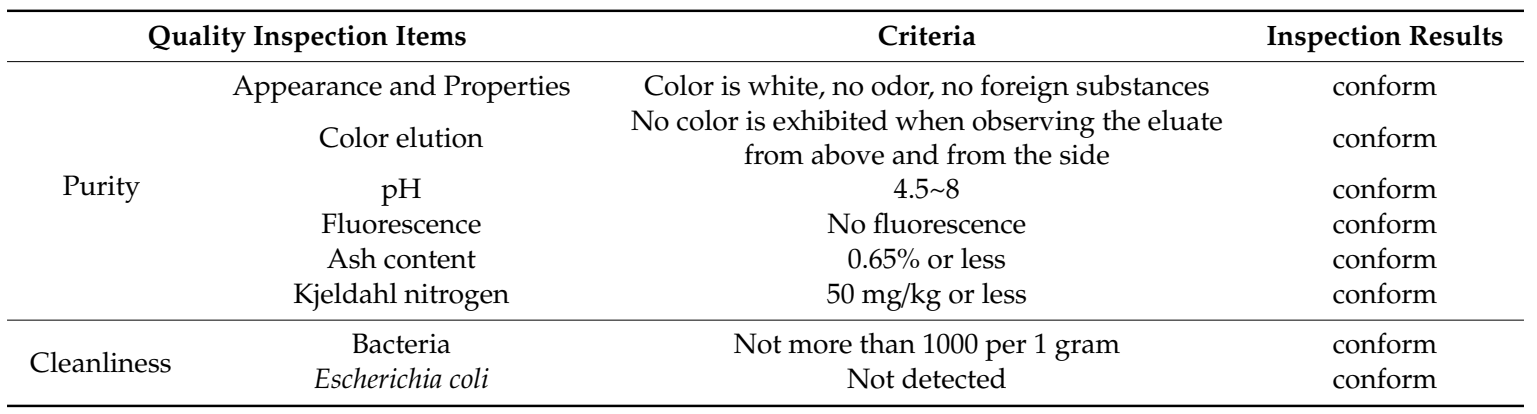

\subsubsection{Functional Unit}

The functional unit is assumed as the "provision of one paper diaper and its disposal." Paper diapers have different material compositions and composition ratios depending on the manufacturer and the shape. The individual material composition ratios for paper diapers for adults and infants (study by Unicharm Corp.) were calculated by weighing them with the individual production volumes [1] to determine the average material composition ratio (see Table 2). In this study, $40.5 \mathrm{~g}$ per paper diaper was adopted for the average weight of all paper diapers, including those for adults (except underwear liners or pads), based on diaper production statistics (2019) [1] (see Table 3). Furthermore, the composition of excreta included in used paper diapers is based on studies by Unicharm Corp. and literature values [19] (see Table 4).

Table 2. Material composition ratio of paper diapers. SAP, superabsorbent polymer.

\begin{tabular}{ccccc}
\hline \multirow{2}{*}{ Materials } & \multicolumn{3}{c}{ Composition Ratio (\%) } \\
\cline { 3 - 5 } & & Average & for Adult & for Infant \\
\hline \multirow{2}{*}{ Pulp } & & 40.9 & 52.2 & 33.3 \\
\multirow{3}{*}{ Plastics } & & 27.9 & 19.8 & 33.3 \\
& Polyethylene & 6.2 & 5.6 & 6.7 \\
& Polypropylene & 18.7 & 16.8 & 20.0 \\
& Polystyrene & 6.2 & 5.6 & 6.7 \\
\hline & Total & 100.0 & 100.0 & 100.0 \\
\hline
\end{tabular}

Table 3. Average weight of paper diapers.

\begin{tabular}{cccc}
\hline Type & $\begin{array}{c}\text { Production Weight } \\
\text { (tonne) }\end{array}$ & $\begin{array}{c}\text { Production Quantity } \\
\text { (1000 pieces) }\end{array}$ & Average Weight (g) \\
\hline for Adult & 365,804 & $5,864,108$ & 62.4 \\
for Infant & 484,079 & $15,094,904$ & 32.1 \\
\hline Total & 849,883 & $20,959,012$ & 40.5 \\
\hline
\end{tabular}

Table 4. Composition of 1 tonne of used paper diapers.

\begin{tabular}{cccc}
\hline \multicolumn{1}{c}{ Composition } & Weight (kg) & Composition Ratio (\%) \\
\hline Paper diaper & 383 & 38.3 \\
Collection bag made of polyethylene & 4 & 0.4 \\
Human excreta & Moisture content & 598 & 61.3 \\
& Solid content & 15 & 100.0 \\
\hline
\end{tabular}




\subsubsection{System Boundary}

The scope from the acquisition of raw materials to the production, distribution, and disposal/recycling of paper diapers was selected as the system boundary. For the use phase, non-use of electric power, fuel, and other utilities were assumed, thus these processes were excluded from the scope of the assessment. Figure 1 illustrates the life cycle flow. As comparable systems, two models using incineration and landfill to treat waste in the disposal/recycling phase were set. For incineration, the combustible general domestic waste treatment currently used in Japan was assumed. For waste power generation, the power generated was assumed to substitute the average purchased power in Japan. For landfill, general waste landfilling was assumed. In this paper, the systems for recycling, landfilling, and incinerating waste in the disposal/recycling phase are called RE, LF, and IN, respectively (see Table 5). Table 6 shows the recycled products and alternative products.

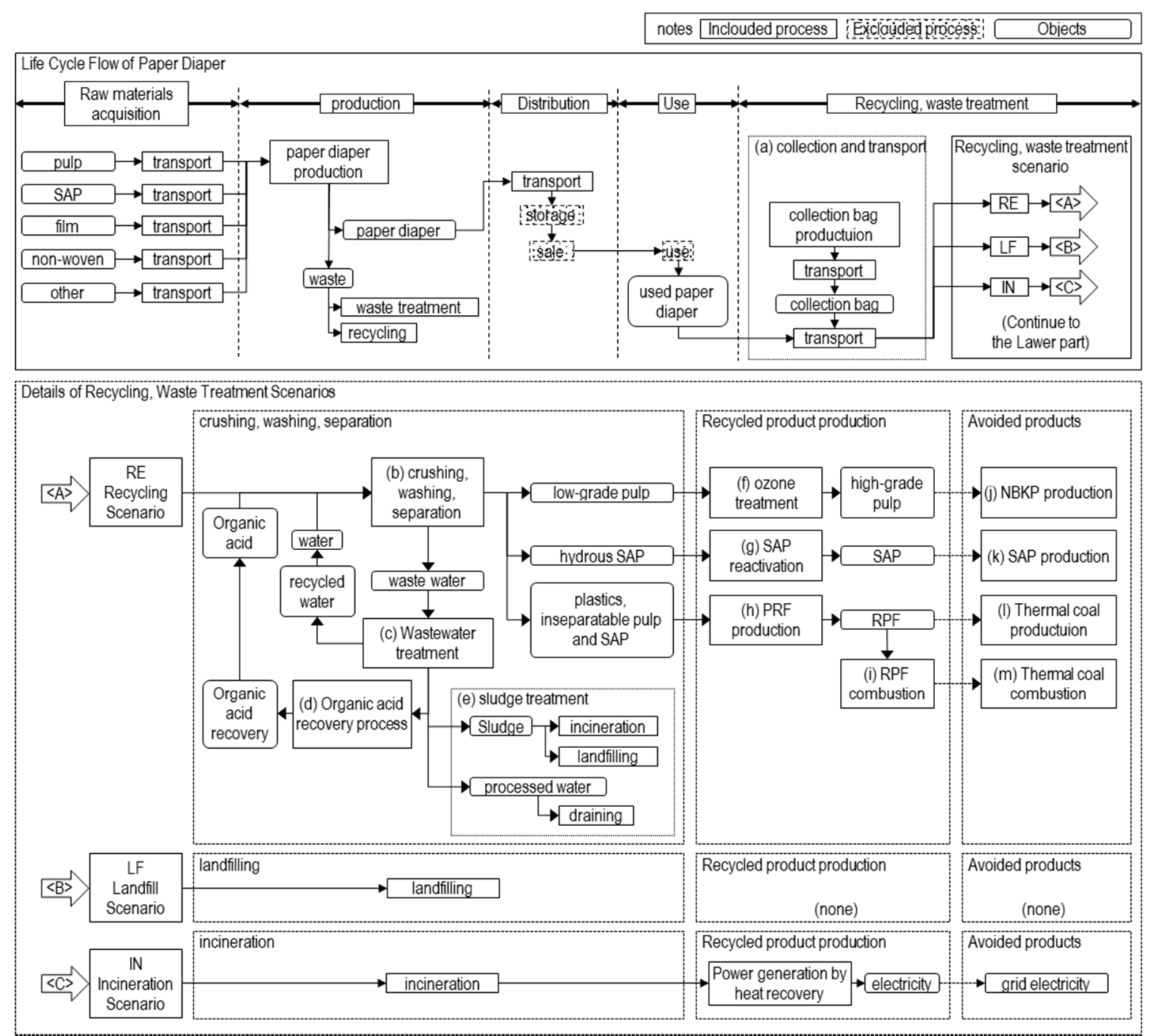

Figure 1. Life cycle flow chart. The upper part shows the life cycle of paper diapers, and the lower part shows details of recycling, waste treatment scenarios. The system boundary is from raw material production, disposable diaper production, transportation, disposal/recycling, production of recycled products, and production of alternative products (excluding storage, sales and use of disposable diapers). RE, recycling; LF, landfill; IN, incineration; RPF, refuse paper and plastic fuel; NBKP, needle bleached kraft pulp. 
Table 5. Scenarios in this study and their differences.

\begin{tabular}{cccc}
\hline \multirow{2}{*}{ Scenario } & Abbreviations & \multicolumn{2}{c}{ Life Cycle Stage } \\
\cline { 3 - 4 } & in This Study & $\begin{array}{c}\text { Raw Materials Acquisition } ~ \\
\text { Production } ~ \text { Distribution } \sim \text { Use }\end{array}$ & Recycling, Waste Treatment \\
\hline Recycling & RE & Common for all scenarios & Recycling \\
Landfill & LF & Landfilling \\
Incineration & IN & Incineration \\
\hline
\end{tabular}

Table 6. Recycled products and alternative products.

\begin{tabular}{cccc}
\hline Scenario & Recycled Products & Alternative Criteria & Alternative Products \\
\hline \multirow{2}{*}{ RE } & Pulp & Mass equivalent & NBKP \\
& SAP & Mass equivalent & SAP \\
LF & RPF & Heat value equivalent & Thermal coal \\
IN & (none) & Electric power & Public power \\
\hline
\end{tabular}

\subsubsection{Impact Categories}

Table 7 shows the impact categories and evaluation methods for the targets. In addition to global warming, land use occupation (maintaining) and water consumption were also included as impact categories closely related to pulp, the main raw material of paper diapers. Furthermore, blue water was considered as the target for water consumption.

Table 7. Environment impact categories and methods in this study.

\begin{tabular}{ccc}
\hline Impact Category & Unit & Evaluation Method \\
\hline Global warming & $\mathrm{kg}-\mathrm{CO}_{2} \mathrm{e}$ & IPCC 2013 GWP 100a \\
Land use occupation & $\mathrm{m}^{2} \mathrm{a}$ & LIME2 [20] \\
Water consumption (blue water) & $\mathrm{m}^{3}$ & water consumption inventory \\
\hline
\end{tabular}

\subsection{Inventory Analysis}

\subsubsection{Data Collection}

1. Raw materials acquisition stage

The input amount of each raw material was determined by multiplying the average material composition ratio for paper diapers for adults and for infants, calculated from their respective composition ratios, by the average weight of paper diapers (see Table 8). For transport, the scenario of importing NBKP from North America via marine transport, and procuring other materials in Japan via land transport using trucks (see Table 9), was used.

2. Production stage

For energy input related to paper diaper production, primary data were collected from the paper diaper plants of Unicharm Corp. Raw material residue generated in the production processes was used as raw materials for pet goods and other products within the same plant; thus, it was assumed that no material loss occurs (see Table 8). 
Table 8. Main collected data and collection methods.

\begin{tabular}{|c|c|c|c|c|}
\hline Life Cycle Stage & Data Item & Data Type & Collected Data & $\begin{array}{l}\text { Data Collection } \\
\text { Method }\end{array}$ \\
\hline $\begin{array}{l}\text { Raw materials } \\
\text { acquisition }\end{array}$ & $\begin{array}{l}\text { Input amount of various } \\
\text { raw materials }\end{array}$ & foreground & $\begin{array}{c}\text { Pulp, SAP, Film, } \\
\text { Non-woven fabric, } \\
\text { others }\end{array}$ & \multirow{2}{*}{$\begin{array}{l}\text { Collected from } \\
\text { Unicharm's paper } \\
\text { diaper factory }\end{array}$} \\
\hline Production & $\begin{array}{l}\text { Energy consumption } \\
\text { Waste amount }\end{array}$ & $\begin{array}{l}\text { foreground } \\
\text { foreground }\end{array}$ & $\begin{array}{c}\text { Electricity } \\
\text { Residue material }\end{array}$ & \\
\hline $\begin{array}{l}\text { Recycling, waste } \\
\text { treatment }\end{array}$ & $\begin{array}{c}\text { Input amount of Energy, } \\
\text { utilities and auxiliary } \\
\text { materials } \\
\text { Pulp recycling rate } \\
\text { SAP recycling rate } \\
\text { Plastics recycling rate } \\
\text { RPF heat value }\end{array}$ & $\begin{array}{l}\text { foreground } \\
\text { foreground } \\
\text { foreground } \\
\text { foreground } \\
\text { foreground }\end{array}$ & $\begin{array}{c}\text { Electricity, LPG, } \\
\text { Industrial water, } \\
\text { Organic acid, } \\
\text { others } \\
80 \% \\
80 \% \\
100 \% \\
36.3 \mathrm{MJ} / \mathrm{kg}\end{array}$ & $\begin{array}{l}\text { Demonstration } \\
\text { experiment data }\end{array}$ \\
\hline
\end{tabular}

Table 9. Transport scenarios.

\begin{tabular}{|c|c|c|c|c|}
\hline Life Cycle Stage & Transport Object & Transport Route & Distance & Mode of Transportation \\
\hline $\begin{array}{l}\text { Raw materials } \\
\text { acquisition }\end{array}$ & $\begin{array}{c}\text { Raw materials and } \\
\text { auxiliary for paper } \\
\text { diapers }\end{array}$ & $\begin{array}{l}\text { Domestic land } \\
\text { transportation } \\
\text { Ocean freight } \\
\text { (From North } \\
\text { America to Japan) }\end{array}$ & $18,707 \mathrm{~km}$ & $\begin{array}{c}10 \mathrm{t} \text { truck, } \\
\text { loading ratio of } 50 \% \\
\text { Container transport ship, } \\
>4000 \text { TEU }\end{array}$ \\
\hline Distribution & $\begin{array}{l}\text { Product (paper } \\
\text { diaper) }\end{array}$ & $\begin{array}{l}\text { Domestic land } \\
\text { transportation }\end{array}$ & $555 \mathrm{~km}$ & $\begin{array}{c}10 \mathrm{t} \text { truck, } \\
\text { loading ratio of } 50 \%\end{array}$ \\
\hline $\begin{array}{l}\text { Recycling, waste } \\
\text { treatment }\end{array}$ & $\begin{array}{c}\text { Used paper diaper } \\
\text { Auxiliary materials } \\
\text { Waste }\end{array}$ & $\begin{array}{l}\text { Domestic land } \\
\text { transportation }\end{array}$ & $\begin{array}{l}100 \mathrm{~km} \\
200 \mathrm{~km} \\
100 \mathrm{~km}\end{array}$ & $\begin{array}{c}2 \mathrm{t} \text { truck, } \\
\text { loading ratio of } 50 \%\end{array}$ \\
\hline
\end{tabular}

\section{Distribution stage}

Paper diapers are generally distributed from the manufacturers to the stores, nursing care facilities, etc., through many distribution channels, which makes it difficult to determine the actual distribution amounts and distribution routes in detail. Therefore, in this study, it was assumed that the diapers are distributed from the paper diaper plants of Unicharm Corp to all 47 prefectures nationwide, with the distribution amounts proportional to the population of individual prefectures. The transport distances for individual prefectures were determined using Google Maps and were then weighed by the transport amount for individual prefectures. For the vehicle class and loading ratio, general domestic transport was assumed (see Table 9).

\section{Use stage}

In this stage, no additional energy was used, so it was excluded from the assessment of environmental impact.

\section{Recycling, waste treatment stage}

For RE or recycling processing, primary data were collected from simulated demonstration experiments at a recycling plant being developed by Unicharm Corp. in Shibushi City, Kagoshima Prefecture that processes about 500 tonnes of waste annually (see Table 8). Eighty percent of the SAP and pulp included in the used paper diapers is recycled, and part of the unrecycled content is mixed with plastics to produce RPF. The plastics are completely recovered and then mixed with part of the unseparated pulp and SAP to produce RPF. For LF and IN, it was assumed that one tonne of used 
paper diapers with the same composition as in RE is processed. Since waste is separately recovered in a polyethylene collection bag of $20 \mathrm{~g}$ per $5 \mathrm{~kg}$ of used paper diapers in RE, it was assumed that the same bags are used in LF and IN and that the scenarios for transport related to waste materials and collection are common to RE, LF, and IN (see Table 9).

\subsubsection{Background Data and Software}

Background data from the Life Cycle Inventory (LCI) database IDEAv2 [21] were mainly used, with missing data complemented by the GHG Emissions Accounting and Reporting Manual [22], and SimaPro 8.5 was used for the calculation.

\section{Results}

\subsection{LCA Results and Comparison between the Three Scenarios}

The LCA results of the system targeted in this study, which assumes the disposal/recycling phase as "recycling processing" in the life cycle, as well as the results for landfill and incineration are shown in Figure 2 and Table 10. The system boundary is the life cycle, including the individual phases from the acquisition of raw materials to the production, use, and disposal/recycling of paper diapers, and the functional unit is the provision of one paper diaper $(40.5 \mathrm{~g})$.
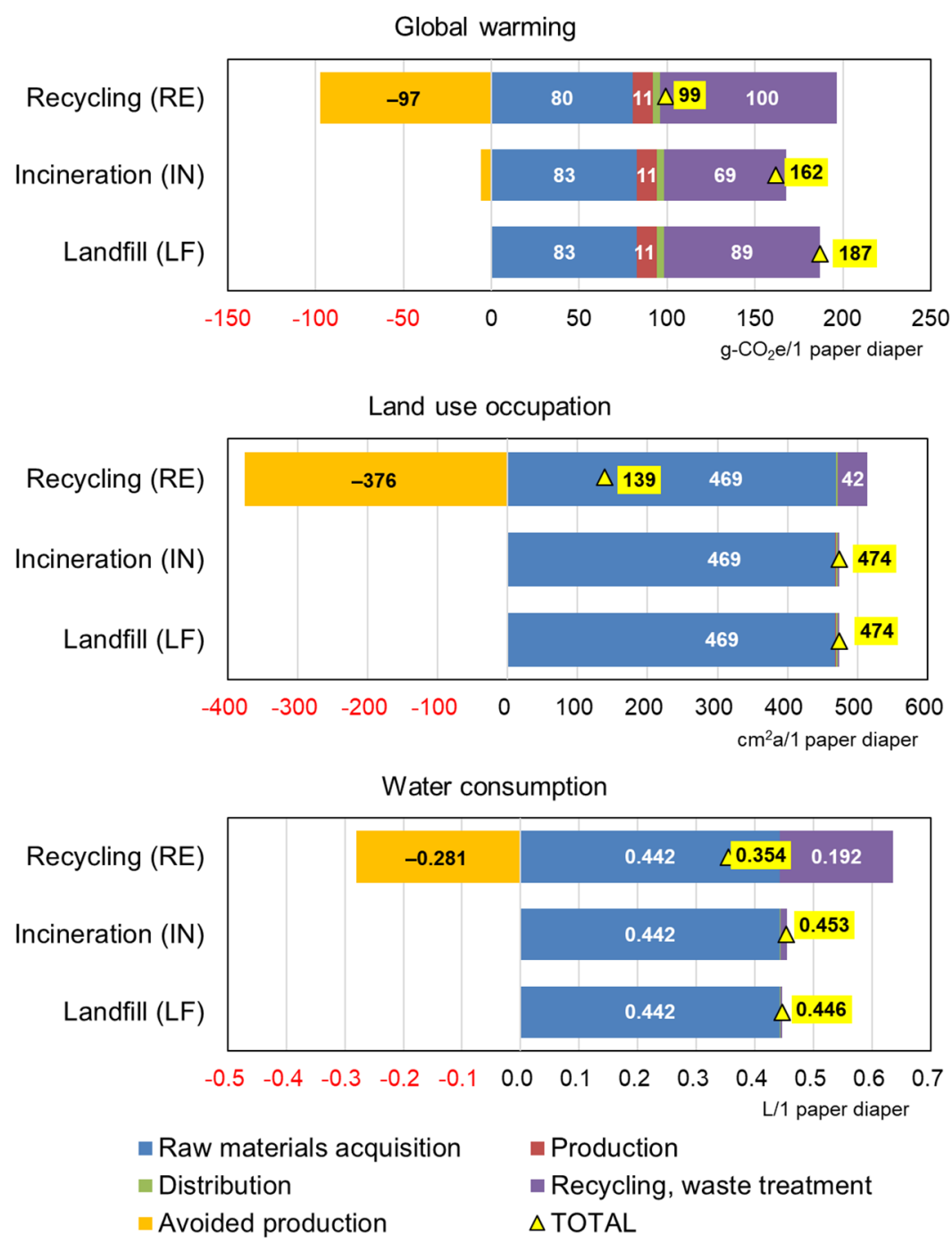

Figure 2. Life cycle assessment (LCA) results and comparison between the three scenarios. 
Table 10. LCA results for each scenario and reduction effect rate.

\begin{tabular}{|c|c|c|c|c|c|}
\hline \multicolumn{3}{|c|}{ Scenario } & $\begin{array}{l}\text { Global Warming } \\
\left(\mathrm{g}-\mathrm{CO}_{2} \mathrm{e}\right)\end{array}$ & $\begin{array}{l}\text { Land Use Occupation } \\
\left(\mathrm{cm}^{2} \mathrm{a}\right)\end{array}$ & $\begin{array}{l}\text { Water Consumption } \\
\text { (L) }\end{array}$ \\
\hline \multirow{3}{*}{ RE } & \multicolumn{2}{|c|}{ Recycling } & 99 & 139 & 0.354 \\
\hline & \multirow{2}{*}{ Reduction rate } & IN $\Delta$ & $39 \%$ & $71 \%$ & $22 \%$ \\
\hline & & $\mathrm{LF} \Delta$ & $47 \%$ & $71 \%$ & $21 \%$ \\
\hline IN & \multicolumn{2}{|c|}{ Incineration } & 162 & 474 & 0.453 \\
\hline $\mathrm{LF}$ & \multicolumn{2}{|c|}{ Landfill } & 187 & 474 & 0.446 \\
\hline
\end{tabular}

\subsubsection{Global Warming}

GHG emissions of IN and LF were calculated as 162 and $187 \mathrm{~g}-\mathrm{CO}_{2} \mathrm{e}$, respectively, while that of RE was estimated at $99 \mathrm{~g}-\mathrm{CO}_{2} \mathrm{e}$, a reduction of $39 \%$ and $47 \%$ compared with IN and LF, respectively. In RE, the amount in the disposal/recycling phase was $100 \mathrm{~g}-\mathrm{CO}_{2} \mathrm{e}$, larger by $11 \%-45 \%$ compared with IN and LF. However, a significant reduction effect compared with IN and LF is expected in the entire life cycle, with the contribution of the total deduction at $97 \mathrm{~g}-\mathrm{CO}_{2} \mathrm{e}$ due to the substitution effect of recycled pulp, SAP, and RPF.

\subsubsection{Land Use Occupation}

The land use occupation values for IN and LF were almost the same at $474 \mathrm{~cm}^{2} \mathrm{a}$, while that for RE was estimated at $139 \mathrm{~cm}^{2}$ a, a reduction of $71 \%$ compared with IN and LF. About $99 \%$ of the loads from IN or LF are due to pulp production included in the raw materials acquisition phase, while RE has a lower value in this phase due to the substitution effect of recycled pulp. Thus, for RE, the load is expected to be reduced in the life cycle.

\subsubsection{Water Consumption}

Water consumption values for IN and LF were calculated at 0.453 and $0.446 \mathrm{~L}$, respectively, about $97 \%$ of which is the contribution from the raw materials acquisition phase, and about $75 \%$ in this phase is the contribution from pulp production and SAP production. The value for RE was $0.354 \mathrm{~L}$, although the ratio in the disposal/recycling phase for RE was $0.19 \mathrm{~L}$, accounting for $53 \%$ of the total compared to $2 \%-3 \%$ for IN and LF, due to the contribution of $0.069 \mathrm{~L}$ of cleaning water and $0.10 \mathrm{~L}$ related to the production of organic acid for cleaning chemicals. Meanwhile, the value for RE in the entire life cycle was estimated to be $21 \%$ and $22 \%$ lower than that for IN and LF, respectively, with the contribution from the substitution effects of recycled pulp and SAP.

\subsection{Detailed LCA Results at Recycling, Waste Treatment Stage of the Recycling Model}

The treatment scenarios targeted in this study are characterized by recycling in the disposal/recycling phase, so the LCA results for disposal/recycling, ranging from collection/transport to production of the recycled products and using the substitution effect (deduction) with the recycled products as the system boundary, are presented in detail (see Table 11). The process IDs in the table correspond to the symbols in (a) to (m) described in the individual processes in Figure 1. The functional unit was the disposal/recycling of one used paper diaper.

\subsubsection{Global Warming}

GHG emissions were calculated at $3.18 \mathrm{~g}-\mathrm{CO}_{2} \mathrm{e}$. Emissions related to the phases from the collection/transport of used paper diapers to the production of recycled products were $100 \mathrm{~g}-\mathrm{CO}_{2} \mathrm{e}$ (subtotal-1), due to a significant contribution of $97.2 \mathrm{~g}-\mathrm{CO}_{2} \mathrm{e}$ (subtotal-2) from the deduction total as a result of NBKP production (j), SAP production ( $\mathrm{k}$ ), as well as thermal coal production and combustion (l), (m), substituted by recycled pulp, SAP, and RPF. Details of the recycling are as follows: $7.8 \%$ for collection/transport (a); 22.7\% for crushing/cleaning/separating (b, c, d, e); and $69.5 \%$ for recycled products production $(\mathrm{f}, \mathrm{g}, \mathrm{h}, \mathrm{i})$. The substitution effects for NBKP production and SAP production were 
$19.3 \%$ and $20.2 \%$, respectively, while that for thermal coal production/combustion was the highest at $60.4 \%$, due to a significant contribution from $\mathrm{CO}_{2}$ direct emissions caused by combustion.

Table 11. Detailed life cycle assessment (LCA) results at the recycling, waste treatment stage.

\begin{tabular}{|c|c|c|c|c|c|}
\hline & Process & $\begin{array}{l}\text { Process } \\
\text { ID }\end{array}$ & $\begin{array}{c}\text { Global } \\
\text { Warming } \\
\left(\mathrm{g}-\mathrm{CO}_{2} \mathrm{e}\right)\end{array}$ & $\begin{array}{l}\text { Land Use } \\
\text { Occupation } \\
\left(\mathrm{cm}^{2} \mathrm{a}\right)\end{array}$ & $\begin{array}{c}\text { Water } \\
\text { Consumption } \\
\text { (L) }\end{array}$ \\
\hline $\begin{array}{l}\text { Collection and } \\
\text { transport }\end{array}$ & Collection and transport & (a) & 7.83 & 1.48 & 0.00282 \\
\hline \multirow{3}{*}{$\begin{array}{l}\text { Crushing, } \\
\text { washing, } \\
\text { and separation }\end{array}$} & $\begin{array}{l}\text { Crushing, washing, } \\
\text { and separation }\end{array}$ & (b) & 9.63 & 39.7 & 0.182 \\
\hline & $\begin{array}{l}\text { Waste water and sludge } \\
\text { treatment }\end{array}$ & $(c, e)$ & 9.53 & 0.320 & 0.00143 \\
\hline & Organic acid recovery & (d) & 3.68 & 0.0628 & 0.000298 \\
\hline \multirow{4}{*}{$\begin{array}{l}\text { Recycled } \\
\text { product } \\
\text { production }\end{array}$} & Ozone treatment & (f) & 5.55 & 0.104 & 0.00100 \\
\hline & SAP reactivation & (g) & 17.0 & 0.307 & 0.00243 \\
\hline & RPF production and combustion & $(h, i)$ & 47.2 & 0.233 & 0.00252 \\
\hline & Subtotal-1, (a) (i) & & 100 & 42.2 & 0.192 \\
\hline \multirow{3}{*}{$\begin{array}{l}\text { Avoided } \\
\text { products }\end{array}$} & NBKP production & (j) & -18.8 & -375 & -0.100 \\
\hline & SAP production & $(\mathrm{k})$ & -19.7 & -0.324 & -0.180 \\
\hline & $\begin{array}{l}\text { Thermal coal production and } \\
\text { combustion }\end{array}$ & $(1, \mathrm{~m})$ & -58.7 & -0.00654 & -0.000690 \\
\hline \multicolumn{2}{|r|}{ Subtotal-2, (j) (m) } & & -97.2 & -376 & -0.281 \\
\hline \multicolumn{2}{|r|}{ Total } & & 3.18 & 333 & -0.0886 \\
\hline
\end{tabular}

\subsubsection{Land Use Occupation}

The land use occupation was $-333 \mathrm{~cm}^{2}$ a, considered as a negative load in the entire process, due to the contribution from the deduction by the substitution effect. Details are as follows: the total of the recycling, from collection/transport to recycled products production (subtotal-1), was $42.2 \mathrm{~cm}^{2} \mathrm{a}$; and the total of the deduction from the substitution effect by recycled products (subtotal-2) was 376 $\mathrm{cm}^{2}$ a. In recycling, the crushing/cleaning/separating phase (b) accounted for the majority at about $94 \%$, which was largely due to the contribution from land use in the plant culturing phase, as the organic acid used was plant-based. Meanwhile, the substitution effect of NBKP production (j) was $375 \mathrm{~cm}^{2} \mathrm{a}$, accounting for almost $100 \%$ of the total at $376 \mathrm{~cm}^{2} \mathrm{a}$, which was due to the significant contribution from land use related to the production of forest resources (softwood) used as materials for virgin pulp, which was avoided by using recycled pulp.

\subsubsection{Water Consumption}

The water consumption per paper diaper was $-0.0886 \mathrm{~L}$ as a whole, a negative value calculated by deducting the substitution effect. Details are as follows: the total of the recycling, from collection/ transport to recycled products production (subtotal-1), was 0.192 L; and the total of the deduction from the substitution effect of recycled products (subtotal-2) was $0.281 \mathrm{~L}$. In recycling, the crushing/cleaning/separating phase (b) accounted for the majority at about $94.5 \%$, among which about $40 \%$ was due to directly consumed water in the cleaning tank, while about $60 \%$ was due to production of the plant-based cleaning agent. 


\section{Discussion}

\subsection{Comparison with Previous Studies}

The results of previous studies related to the recycling of used paper diapers were reviewed and compared with this study. As previous studies assess only the disposal/recycling phase in the life cycle of paper diapers, the disposal/recycling process from the results of this study were extracted and the system boundary was set to cover "disposal/recycling of one tonne of used paper diapers" only (see Table 12).

Table 12. Comparison with previous studies. The functional unit is recycling, waste treatment of 1 tonne of used paper diapers.

\begin{tabular}{|c|c|c|c|c|c|}
\hline \multirow[b]{2}{*}{$\begin{array}{l}\text { Comparative } \\
\text { Studies }\end{array}$} & \multicolumn{4}{|c|}{ GHG Emissions $\left(\mathrm{kg}-\mathrm{CO}_{2} \mathrm{e}\right)$} & \multirow[b]{2}{*}{ Recycled Products } \\
\hline & $\begin{array}{c}\text { Collection and } \\
\text { Transport }\end{array}$ & $\begin{array}{l}\text { Recycling, Waste } \\
\text { Treatment }\end{array}$ & $\begin{array}{l}\text { Recycling } \\
\text { Effect }\end{array}$ & Total & \\
\hline \multicolumn{6}{|l|}{ This study } \\
\hline Recycling & 74 & 875 & -919 & 30 & $\begin{array}{c}\text { Pulp (127 kg) } \\
\text { SAP (91 kg) } \\
\text { RPF (155 kg) }\end{array}$ \\
\hline Incineration & 74 & 579 & -55 & 598 & Electricity (91 kWh) \\
\hline Landfill & 74 & 764 & 0 & 838 & (None) \\
\hline \multicolumn{6}{|c|}{ Comparative studies } \\
\hline \multicolumn{6}{|l|}{ Itsubo et al. [8] } \\
\hline Recycling & 55 & 1132 & -821 & 366 & $\begin{array}{l}\text { Pulp (89 kg) } \\
\text { RPF (306 kg) }\end{array}$ \\
\hline Incineration & 55 & 523 & -85 & 493 & Electricity $(137 \mathrm{kWh})$ \\
\hline \multicolumn{6}{|c|}{ Fujiyama et al. [6] } \\
\hline Recycling & $\begin{array}{c}\text { (out of } \\
\text { boundary) }\end{array}$ & 530 & -240 & 290 & $\begin{array}{c}\text { Pulp }(159 \mathrm{~kg}) \\
\text { Fermented fertilizer }\end{array}$ \\
\hline Incineration & $\begin{array}{c}\text { (out of } \\
\text { boundary) }\end{array}$ & 432 & (none) & 432 & (None) \\
\hline
\end{tabular}

Among the domestic studies, Itsubo et al. [9] discuss closed-loop recycling. The paper targeted the closed-loop recycling of recycling pulp as fine pulp usable as raw materials for paper diapers, where plastics and SAP were converted to RPF for thermal recycling. Compared with the present study, this system as characterized by a lower pulp recycling amount by about $30 \%$, but a higher RPF recycling amount of about two-fold. The calorific value for RPF as lower by about $34 \%$, making the total of the substitution effect (deduction) smaller by about $10 \%$. The total GHG emissions related to recycling was about 1.3 times that of the present study, which resulted in a total-including the deduction-at $366 \mathrm{~kg}-\mathrm{CO}_{2} \mathrm{e}$, which was about 12 times the value in this study at $30 \mathrm{~kg}-\mathrm{CO}_{2} \mathrm{e}$. Compared with the study by Itsubo et al., GHG emissions related to recycling in this study were reduced by $23 \%$, while the recycling ratio of pulp was about $80 \%$. For RPF, the contamination rate of pulp and SAP residues other than plastics was low, resulting in a higher calorific value, and the deduction was higher due to SAP recycling, significantly reducing GHG emissions as a whole.

In the study by Fujiyama et al. [6], the GHG emissions related to recycling were about $60 \%$ of the value obtained in the present study, but the substitution effect (deduction) in their study was about a quarter of the value obtained in the present study at $240 \mathrm{~kg}-\mathrm{CO}_{2} \mathrm{e}$. This is presumably caused by a lower deduction range per unit of weight of recycled products compared to the present study as Fujiyama et al. used downgrade recycling. 
The study report on the processing equipment for thermal recycling of used paper diapers as solid fuel [7] indicates the possible reduction of $\mathrm{CO}_{2}$ emissions by using such fuel as a substitute for fossil fuel, but that effect was excluded from the comparison as the effect was not quantified.

Note that the values in the present study cannot be directly compared with those in previous studies as the prerequisites differ in the following points.

1. The system boundaries are not always the same in studies, such as the inclusion of the collection/transport process.

2. Individual studies may use different background databases, resulting in different environmental loads, even with the same inventory.

3. The composition of used paper diapers (material composition of used paper diapers, the ratio of excretion in paper diapers, etc.) differs by study, which results in, for example, a different yield in recycled products, even with the same recycling ratio.

4. The suitability of recycled products is not sufficiently assessed. If recycled products substitute virgin materials in equal amounts, the quality of the former should be sufficiently verified. It is also necessary to assess the market demand. Sufficient information on these matters cannot be obtained from a comparison with previous studies.

5. Values not provided in the report by Fujiyama et al. were directly measured using a chart, which may have errors.

\subsection{Estimation of the Potential for Environmental Load Reduction}

The potential for environmental load reduction by recycling used paper diapers in Japan and the world was estimated from reduction amounts obtained in this study and by applying them to the incineration and landfill baselines of Japan and the world (see Table 13). The annual production volume of paper diapers for adults and infants in Japan was 878,000 tonnes. The waste weight was estimated at 2.294 million tonnes, assuming that the disposal weight increase factor was 2.6; this is due to the increased weight from excretion. Based on this waste amount and the ratio of 98:2 for incineration vs. landfill, the reduction potential nationwide was estimated at about 1.314 million $\mathrm{t}-\mathrm{CO}_{2} \mathrm{e}$ for $\mathrm{GHG}$ emissions, $726 \mathrm{~km}^{2}$ a for land use occupation, and 2.149 million $\mathrm{m}^{3}$ for water consumption.

Table 13. Estimation of the potential for environmental load reduction.

\begin{tabular}{|c|c|c|c|c|c|c|}
\hline & \multirow[b]{2}{*}{ Unit } & \multicolumn{2}{|c|}{ Incineration } & \multicolumn{2}{|c|}{ Landfill } & \multirow{2}{*}{$\begin{array}{l}\text { Total Amount } \\
\text { of Reduction } \\
\text { per Year }\end{array}$} \\
\hline & & $\begin{array}{l}\text { Current } \\
\text { Estimates }\end{array}$ & $\begin{array}{c}\text { Apply } \\
\text { Recycling }\end{array}$ & $\begin{array}{c}\text { Current } \\
\text { Estimates }\end{array}$ & $\begin{array}{c}\text { Apply } \\
\text { Recycling }\end{array}$ & \\
\hline Paper diaper production & Mt/year & \multicolumn{4}{|c|}{0.878} & - \\
\hline Disposal volume & Mt/year & \multicolumn{4}{|c|}{2.294} & - \\
\hline Environmental load per year & & \multicolumn{2}{|c|}{2.248} & \multicolumn{2}{|c|}{0.046} & - \\
\hline Global warming & $\mathrm{Mt}-\mathrm{CO}_{2} \mathrm{e}$ & 1.344 & 0.068 & 0.038 & 0.001 & 1.314 \\
\hline Land use occupation & $\mathrm{km}^{2} \mathrm{a}$ & 4 & -708 & 0.1 & 14 & 726 \\
\hline Water consumption & $\mathrm{Mm}^{3}$ & 0.222 & -1.881 & 0.006 & -0.038 & 2.149 \\
\hline \multicolumn{7}{|l|}{ Global } \\
\hline Ratio of disposal method & $\%$ & \multicolumn{2}{|c|}{$37 \%$} & \multicolumn{2}{|c|}{$63 \%$} & - \\
\hline Amount by disposal method & Mt/year & \multicolumn{2}{|c|}{4.706} & \multicolumn{2}{|c|}{8.014} & - \\
\hline Environmental load per year & & & & & & - \\
\hline Global warming & $\mathrm{Mt}-\mathrm{CO}_{2} \mathrm{e}$ & 2.814 & 0.142 & 6.712 & 0.241 & 9.143 \\
\hline Land use occupation & $\mathrm{km}^{2} \mathrm{a}$ & 8 & -1482 & 13 & -2524 & 4027 \\
\hline Water consumption & $\mathrm{Mm}^{3}$ & 0.466 & -3.938 & 1.111 & -6.706 & 12.221 \\
\hline
\end{tabular}


Overseas, the annual production volume of paper diapers was estimated at 120 billion [23], but the weight per diaper is unknown. Thus, the production volume for the world was estimated at 4.866 million using the average weight of $40.5 \mathrm{~g}$ for diapers for adults and infants produced in Japan. The weight increase factor for disposal was set at the same value as in Japan, or 2.6, and the waste weight was estimated at 12.720 million tonnes. The ratios of the processing methods were set at $63 \%$ for landfill and $37 \%$ for incineration [24]. Using these prerequisites, it was estimated that the GHG emissions reduction potential was 9.143 million tonnes- $\mathrm{CO}_{2} \mathrm{e}$, land use occupation was $4027 \mathrm{~km}^{2} \mathrm{a}$, and water consumption was 12.221 million $\mathrm{m}^{3}$ when applying recycling throughout the world (see Table 13).

The estimates were based on the assumption that all used paper diapers produced in Japan and the world are recycled, which requires the following cautions.

- No comparative study on costs has been conducted, so it is uncertain if economic rationality is achieved in all regions.

- It is uncertain if a system to recover used paper diapers for recycling facilities can be established, as the disposal methods for used paper diapers differ by nation or region.

- It is uncertain if the destinations for using recycled products can be established in all regions.

\section{Conclusions}

As the production of paper diapers is expected to increase in the future, there is a strong need for an appropriate recycling technology in terms of waste treatment after use and for sustainable use of resources. While previous studies and cases are limited to open-loop recycling, the present study achieved closed-loop recycling of pulp and SAP from "paper diapers to paper diapers" thanks to a new technology, thus clarifying that the environmental load can be further reduced compared to that in the preceding report [9] in the assessment of GHG emissions, water consumption, and land use occupation for the life cycle of recycling used paper diapers (see Table 14). The recycling technology in this study demonstrated a high recycling effect by enabling the recycling of high-quality pulp and SAP. In the future, further reductions in environmental impact are expected through the efficiency of SAP regeneration and the improvement of the recycling rate. On the other hand, in this study, it was considered that uncertainties were included from the following points, but even if these factors are taken into consideration, a significant reduction in environmental load was confirmed.

Table 14. Reduction of environmental load by the recycling technology of this study and other recycling technologies.

\begin{tabular}{|c|c|c|c|c|}
\hline \multicolumn{4}{|c|}{ This Study } & \multirow{3}{*}{$\begin{array}{l}\text { Other Recycling } \\
\text { Technologies }\end{array}$} \\
\hline \multirow[b]{2}{*}{ System Boundary } & \multirow[b]{2}{*}{ Impact Category } & \multicolumn{2}{|c|}{ Reduction Rate } & \\
\hline & & $\begin{array}{l}\text { Compared with } \\
\text { Incineration }\end{array}$ & $\begin{array}{l}\text { Compared with } \\
\text { Landfill }\end{array}$ & \\
\hline \multirow{3}{*}{ Full life cycle * } & Global warming & $39 \%$ & $47 \%$ & \multirow{3}{*}{$\begin{array}{l}\text { Previous studies in Japan } \\
\text { have not evaluated the full } \\
\text { life cycle. }\end{array}$} \\
\hline & Land use occupation & $71 \%$ & $71 \%$ & \\
\hline & Water consumption & $22 \%$ & $21 \%$ & \\
\hline $\begin{array}{l}\text { Recycling, waste } \\
\text { treatment stage }\end{array}$ & Global warming & $95 \%$ & $96 \%$ & $\begin{array}{l}\text { Itsubo et al. [9] reported a } \\
26 \% \text { reduction, } \\
\text { and Fujiyama et al. [6] } \\
\text { reported a 33\% reduction in } \\
\text { GHG emissions. }\end{array}$ \\
\hline
\end{tabular}

* Full life cycle includes all life cycle stages of the paper diaper, from the acquisition of the raw materials to the recycling, waste treatment stage, except for the use stage.

The recycling facility from which the data were collected is a prototype, so its representativeness may be low. 
- Japanese data were used for LCA calculations.

- Thermal coal and electricity were set as alternative products for the recycling effect. However, if these are changed to other products, the recycling effect may change.

In addition, it is expected that the recycling process of this study will have great social and economic benefits. Analyses focused on social and economic aspects were also assumed, but were not included in this study due to the difficulty in obtaining data, etc., and the immature evaluation method.

Author Contributions: Conceptualization, N.I., M.W., and K.S.; methodology, N.I., N.M., and K.S.; validation, N.I., N.M., and K.S.; formal analysis, A.M. and N.M.; investigation, M.W., S.I., and A.M.; resources, M.W., S.I., and A.M.; writing-original draft preparation, N.M.; writing—review and editing, N.M.; supervision, M.W.; project administration, M.W. All authors read and agreed to the published version of the manuscript.

Funding: This research received no external funding.

Conflicts of Interest: The authors declare no conflicts of interest.

\section{References}

1. Ministry of Economy, Trade and Industry. Yearbook of Current Production Statistics Paper, Printing, Plastic Products and Rubber Products Statistics. 2018. Available online: https://www.meti.go.jp/statistics/tyo/seidou/ result/ichiran/resourceData/06_kami/nenpo/h2dgg2018k.xls (accessed on 26 December 2019).

2. Cabinet Office, Government of Japan. Annual Report on the Ageing Society [Summary] FY. 2019. Available online: https:/www8.cao.go.jp/kourei/whitepaper/w-2019/zenbun/pdf/1s1s_01.pdf (accessed on 26 December 2019).

3. Japan Hygiene Products Industry Association (JHPIA). Paper Diaper News No.36. May 2001. Available online: http://www.jhpia.or.jp/pdf/news36.pdf (accessed on 19 November 2019).

4. Ministry of Land, Infrastructure, Transport and Tourism. Basic Information about Disposable Diapers. Available online: http://www.mlit.go.jp/common/001220454.pdf (accessed on 19 November 2019).

5. Japan Hygiene Products Industry Association (JHPIA). Paper Diaper News No.58. Febuary 2007. Available online: http://www.jhpia.or.jp/pdf/news58.pdf (accessed on 19 November 2019).

6. Fujiyama, A.; Sakurai, T.; Matsumoto, T.; Cho, T. Environmental Evaluation of Pulp Reuse by Recycling of Used Disposable Diapers. J. Life Cycle Assess. Jpn. 2012, 8, 37-44. [CrossRef]

7. Gerina-Ancane, A.; Eiduka, A. Research and analysis of absorbent hygiene product (AHP) recycling. Eng. Rural Dev. Jelgava 2016, 5, 904-910.

8. Tsuji, N.; Takahashi, H.; Sekine, K. Trial of making fuel from wasted diaper in Furano city, Hokkaido. In Proceedings of the 10th Conference on Biomass Science, Ibaraki, Japan, 14-15 January 2015; The Japan Institute of Energy: Tokyo, Japan.

9. Itsubo, N.; Imai, S.; Wada, M.; Kamosawa, T.; Okano, M.; Makino, N.; Shobatake, K. Environmental Evaluation of Pulp Reuse by Recycling of Used Disposable Diapers. Environ. Inf. Sci. 2016, 30, 329-334.

10. The Public Waste Agency of Flanders (OVAM). Potential for Circularity of Diapers and Incontinence Material through Eco-Design. Available online: https:/www.ovam.be/sites/default/files/atoms/files/Report\% 20TWOL\%20study\%20final-\%20EN-\%20OVAM.pdf (accessed on 28 February 2019).

11. CE Delft, LCA of Waste Treatment of Diaper Material. Available online: https://cedelft.org/en/publications/ download/2459 (accessed on 28 February 2019).

12. Arena, U.; Ardolino, F.; Di Gregorio, F. Technological, environmental and social aspects of a recycling process of post-consumer absorbent hygiene products. J. Clean. Prod. 2016, 127, 289-301. [CrossRef]

13. Deloitte UK. Absorbent Hygiene Products Comparative Life Cycle Assessment. Available online: http:// www.knowaste.com/wp-content/uploads/2018/02/Deloitte-dcarbon8_Knowaste-LCA_Exec_Summary.pdf (accessed on 8 June 2018).

14. International Organization for Standardization, ISO 14040:2006 Environmental Management-Life Cycle Assessment-Principles and Framework; International Organization for Standardization: Geneva, Switzerland, 2006. 
15. Japan Platform for Patent information, Unicharm Corporation, Method for Decomposing Used Sanitary Goods and Method for Separating Pulp Fiber from Used Sanitary Goods, Patent Publication No. 2017-209675. Available online: https://www.j-platpat.inpit.go.jp/c1800/PU/JP-2017209675/0D90568A42028BBB76CB9E93D1A81E3ED57D76187780BFED6832A766F6DB65B6/11/en (accessed on 21 August 2018).

16. Japan Platform for Patent Information, Unicharm Corporation, Method for Recovering Pulp Fibers from Used Hygiene Products, Patent Publication No. 2014-217835. Available online: https://www. j-platpat.inpit.go.jp/c1800/PU/JP-2014-217835/FEFC067D3D26B82407F89A399769D04B43F45CC225405AD307 2259BD91DCE929/11/en (accessed on 21 August 2018).

17. Japan Platform for Patent Information, Hokkaido University; Unicharm Corporation, Method for Recycling Used Superabsorbent Polymer. Patent Publication No.; 2013-198862. Available online: https://www.j-platpat.inpit.go.jp/c1800/PU/JP-2013-198862/34AB94B35BD1E26DF1BE49A6854F435FAB1ECCC 46D84D2444479C91569295773/11/en (accessed on 21 August 2018).

18. Ministry of Health, Labour and Welfare, The Japanese Specifications of Sanitary Napkin Materials. Available online: https://www.mhlw.go.jp/file/06-Seisakujouhou-11120000-Iyakushokuhinkyoku/seiri_zairyou.pdf (accessed on 26 December 2019).

19. Kobayashi, J.; Morii, F.; Muramoto, S.; Nakajima, S. Chemical investigation on inorganic constituents in night soil (excreta) II. Nogaku kenkyu 1976, 55, 161-176.

20. LCA Society of Japan. LIME2 Library. Available online: https://ca-forum.org/english/news/index.html\#lime2 (accessed on 19 November 2019).

21. Research Laboratory for IDEA, Research Institute of Science for Safety and Sustainability, National Institute of Advanced Industrial Science and Technology (AIST); Sustainable Management Promotion Organization (SuMPO), LCI database IDEA version 2. Available online: http://www.idea-lca.jp/index.html (accessed on 2 November 2018).

22. Ministry of the Environment. GHG Emissions Accounting and Reporting Manual (ver4.4). Available online: https://ghg-santeikohyo.env.go.jp/files/manual/chpt2_4-4.pdf (accessed on 18 July 2019).

23. Nippon shokubai CO., LTD. Available online: https://www.shokubai.co.jp/ja/recruit/graduate/keyword/02. html (accessed on 19 November 2019).

24. Cordella, M.; Bauer, I.; Lehmann, A.; Schulz, M.; Wolf, O. Evolution of disposable baby diapers in Europe: Life cycle assessment of environmental impacts and identification of key areas of improvement. J. Clean. Prod. 2015, 95, 322-331. [CrossRef]

(C) 2020 by the authors. Licensee MDPI, Basel, Switzerland. This article is an open access article distributed under the terms and conditions of the Creative Commons Attribution (CC BY) license (http://creativecommons.org/licenses/by/4.0/). 